\title{
CLIL AND GLOBAL EDUCATION: A MEANINGFUL MATCH
}

\author{
Zuzana Straková \\ University of Presov, Slovakia
}

\begin{abstract}
Education for future necessarily embraces multiple skills and themes which are transversal and applicable across the curriculum content. Students need to see and understand the content of individual subjects as connected and not as a discrete entity. CLIL as an approach which focuses on integration of meaningful context into a language learning classroom has been tested over the last decades and demonstrates that communication does not necessarily need to be limited to vocabulary and grammar practice. On the contrary as one of the global skills communication supports social interaction in problem solving, collaboration and thus is the key skill in achieving target goals. This study focuses on the readiness to implement the global skills within the CLIL approach among trainees in their last year of teacher training in Slovakia in 2019. The questionnaires and the subsequent interviews reveal that future language teachers still seem to prefer focusing on pure language aims to integrating global skills development and they even lack the confidence in application of transversal themes and skills. Even though there is a clear understanding of the importance of integration of global skills into education in general the lack of their own experience seems to determine their attitude towards them. These results identify the space for modification in the teacher training curriculum; however, it requires a wider cooperation within different subjects.
\end{abstract}

Keywords: CLIL, critical thinking, creativity, global skills in education, intercultural competence, language teacher training.

\section{Introduction}

Innovation within foreign language education represents various concepts in various educational contexts. The reasons for innovation in language pedagogy can also differ depending on the conditions by which the language teaching is determined. Yet, globalisation embedded in the modern world has left its imprint also in the way languages are taught. Best examples can be seen in classrooms where the integration of content of other school subjects widens understanding of what it means to teach language as a skill. The shift from the focus on form, so thoroughly applied by traditional teaching methods, towards the content started already in the past century by introducing Communicative language teaching and continued towards making language teaching more meaningful and useful to learners. 
The beginning of new millennium even strengthened this tendency due to the spread of the Content and Language Integrated Learning (CLIL) as an approach of innovative, meaningful and active learning. The grounding premises within language learning suddenly did not limit to practising four language skills; instead it started to focus on transversal skills which might be applicable across the curriculum (Marsh, 2006).

This study focuses on the readiness of future teachers to see and understanding of crossroads in the school curriculum and their ability to develop global skills of their students in teaching foreign languages.

\section{Literature Review}

Integrating content and language started to dominate professional discussions towards the end of 20th century (Mehisto et al., 2008; Marsh, 2002) and highlighted the benefits the students could gain by combining the content of other school subjects and English learning in dual-focused approach (Mehisto, 2012). Students who get involved in solving a problem task, where the focus is on the content subject, will primarily direct their attention to work on the content (Pokrivčáková, Menzlová, \& Farkašová, 2010) and the foreign language will serve as a tool for receiving or sending a message. Placing the learning process on the wider support of the context opens opportunities for cooperative and active learning (Cummins, 1998). Such tasks are rarely present in general language textbooks, where the underlying language structure or vocabulary will remain a guiding principle for the practice and usually even the end product itself. Furthermore, as Ch. Dalton-Puffer, T. Nikula and U. Smit (2010, p. 279) claim CLIL classes offer more "interactional space for students" together with "a range of communicative intentions that are not typical of most EFL lessons".

Research studies focusing on the learning outcomes of CLIL implementation highlight the gains on both sides of continuum of content-based instruction (Met, 1998) not only language benefits but also gains in the content subject (Cenoz, 2009; Dalton-Puffer, 2011). However, the educational and sociocultural context will usually determine the choice of framework and the degree of integration (Ruiz de Zarobe, \& Cenoz, 2015).

Students who are engaged in CLIL learning will need to apply and execute much wider repertoire of skills and strategies (Sepešiová, 2015; Ridder, 2004; Jakar, 2004) in comparison to situations solely focusing on language structures or functions and raise chances for incidental learning of the target language (Lorenzo, Casal, \& Moore, 2010). This creates the space for the focus on skills beyond the language scope and provides the opportunities to connect language learning with themes of global nature. Rascón-Moreno supports this by stating 
that "addressing global issues in the English classroom is a way of transmitting content and teaching language at the same time” (Rascón-Moreno, 2013, p. 28).

Globalisation has influenced many areas of human life and it is reflected also in the way professionals started to view the role of education and the needs defined for new millennium. Last two decades of the 20th century placed the focus on such issues that were common to all countries or as Díaz-Pérez states to people as "citizens of the world" with a further specification to themes as "poverty, inequality, or international trade, but also environmental issues such as climate change or deforestation, or all those aspects related to human rights" (Díaz-Pérez, 2013, p. 8).

Inclusion of global themes has been supported also by the major international associations of teachers (International Association of Teachers of English as a Foreign Language - IATEFL, Teachers of English to Speakers of Other Languages - TESOL as well as Japan Association for Language Teaching - JALT by making global issues section a regular part of their conferences (RascónMoreno, 2013).

In this sense it became desirable to focus the attention not only on global theme but also to identify transversal competencies (UNESCO, 2017) or global skills applicable across curriculum.

Global skills have been a part of sustainable education for quite some time (e.g. Burke, 1989; Rychen \& Salganik, 2003; Klieme, Hartig, \& Rauch, 2008; Wiek, Withycombe, \& Redman, 2011) and have been presented in many different frameworks (e.g. UNESCO, 2017; OECD, 2016). General outlining of competencies required within educational context (e.g. Díaz-Pérez, 2013) allowed more thorough investigation of possible intersections with language teaching. The design of specific framework for English (Mercer et al., 2019) included the skills which are relevant and linked to learning foreign languages. There were five clusters designed: 1. Communication and collaboration, 2. Creativity and critical thinking, 3. Intercultural competence and citizenship, 4. Emotional selfregulation and wellbeing, 5. Digital literacies (Mercer et al., p. 8). These cluster seem to cover those skills which not only are relevant for language learning but also enable the user of the language to function properly in the future in intercultural communication.

The very important role in implementation of global skills is also put on the stakeholders at all levels. Teachers will hardly start the shift in traditional ways of teaching without support and supportive environment, which includes continuous professional development. However, the most effective might be to start at pregradual level within general teacher preparation. 


\section{Methodology}

The research sample consisted of 35 participants, English majors (n=35), in their last year of pre-service teacher training in Slovakia, the University of Presov in 2019. The data collection was carried out after they have concluded their ELT Methodology training and have experienced two school placements at elementary and secondary level. Majority of participants (27) were double majors, i.e. they study one more school subjects as their major besides the English language. Eight participants were single majors, i.e. they major only in the English language. Five double major participants have Civics as their other major. This information is relevant for the data analysis since there will be a clear distinction between these five participants and the rest of the participants in the number of lessons they have experienced in the global skills training. Since the issue of teaching global skills was not a part of the English Language Methodology syllabus, the lecturer spent three lessons presenting the concept of global skills to the students as well as the possibilities for implementation of global skills into their own teaching.

The aim of the study was to find out how ready the students felt about including general global themes and the development of global skills into a very specific curriculum, traditionally oriented on language skills training, via content and language integrated learning (CLIL). The reason for choosing CLIL lessons for global skills development was the idea that CLIL lessons are often based on similar premises as global skills and thus these can be used within CLIL lessons more easily than in a standard language-focused lesson.

The research primarily focused on the amount of experience the students of teacher training have had in the area of global skills and on how well they feel prepared to implement these skills into their teaching. Secondly it aimed at examining their readiness to match global skills development within CLIL teaching. As the research was based in the context of CLIL it was desirable to introduce the idea of developing global skills in the CLIL lesson. Therefore, the students were presented a few activities of each global skills cluster (based on Mercer et al., 2019) within a variety of themes.

The study uses quantitative research methods. The collection of data was based on a questionnaire with 20 questions and 19 of them used the response scale for all items of Likert rating scale coded as follows: Strongly/Moderately/Slightly Disagree - Neutral - Slightly/Moderately/Strongly Agree. This type of response scale has been chose in order to provide students with a wider variety of options. One questionnaire item required the information about the amount of experience with global skills in the teacher preparation in hours. 


\section{Research results}

The data gathered through the questionnaire were analysed using Statistica software v13. The table below provides the descriptive statistics where individual variables correspond to the number of the questionnaire items (see Tab. 2). It can be seen that respondents in general evaluated their readiness to implement global skills into their teaching surprisingly high as well as their readiness to match global skills development within CLIL teaching very positively (see mean and median values in Table 1). This fact seems to be surprising due to the fact that their experience with global skills was rather limited, except for five respondents (see Fig. 2).

Table 1 Descriptive statistics CLIL and global skills

\begin{tabular}{|c|c|c|c|c|c|c|}
\hline \multirow[b]{2}{*}{ Variable } & \multicolumn{6}{|c|}{ Descriptive Statistics (CLIL vs GS) } \\
\hline & Yalid N & Mean & Median & Minimum & Maximum & Std.Dex \\
\hline Q1 & 35 & 6,03 & 6,0 & 3,0 & 7,0 & 1,01 \\
\hline Q2 & 35 & 6,34 & 7,0 & 4,0 & 7,0 & 0,80 \\
\hline Q3 & 35 & 6,17 & 6,0 & 4,0 & 7,0 & 0,89 \\
\hline Q4 & 35 & 6,43 & 7,0 & 5,0 & 7,0 & 0,78 \\
\hline Q5 & 35 & 4,29 & 5,0 & 2,0 & 7,0 & 1,43 \\
\hline Q6 & 35 & 5,97 & 6,0 & 4,0 & 7,0 & 0,86 \\
\hline Q7 & 35 & 5,77 & 6,0 & 3,0 & 7,0 & 1,19 \\
\hline Q8 & 35 & 5,60 & 6,0 & 4,0 & 7,0 & 1,03 \\
\hline Q9 & 35 & 5,97 & 6,0 & 4,0 & 7,0 & 0,98 \\
\hline Q10 & 35 & 6,09 & 6,0 & 4,0 & 7,0 & 0,89 \\
\hline Q11 & 35 & 6,06 & 6,0 & 4,0 & 7,0 & 0,73 \\
\hline Q12 & 35 & 5,80 & 6,0 & 4,0 & 7,0 & 0,90 \\
\hline Q13 & 35 & 5,54 & 6,0 & 4,0 & 7,0 & 0,92 \\
\hline Q14 & 35 & 5,91 & 6,0 & 4,0 & 7,0 & 0,89 \\
\hline Q15 & 35 & 5,66 & 6,0 & 3,0 & 7,0 & 1,08 \\
\hline Q16 & 35 & 6,51 & 7,0 & 4,0 & 7,0 & 0,78 \\
\hline Q17 & 35 & 6,11 & 6,0 & 4,0 & 7,0 & 0,93 \\
\hline Q18 & 35 & 6,20 & 6,0 & 4,0 & 7,0 & 0,80 \\
\hline Q19 & 35 & 5,83 & 6,0 & 30 & 7,0 & 1,01 \\
\hline
\end{tabular}

Table 2 Legend to the graphs and figures

1. Global skills should be a part of every school subject.

2. CLIL in teaching English offers space for including global skills.

3. Teaching across curriculum is meaningful.

4. I can imagine including global skills in e.g. CLIL teaching.

5. I find it more difficult to identify content aims than language aims for CLIL lessons.

6. I think there is a clear connection between CLIL teaching and global skills development.

7. I can imagine developing global skills in any English language lesson.

8. I can see clearly how I would develop communication cluster in my teaching.

9. I can see clearly how I would develop collaboration cluster in my teaching.

10. I can see clearly how I would develop creativity cluster in my teaching.

11. I can see clearly how I would develop critical thinking cluster in my teaching.

12. I can see clearly how I would develop intercultural competence cluster in my teaching.

13. I can see clearly how I would develop citizenship cluster in my teaching.

14. I can see clearly how I would develop emotional self-regulation and wellbeing cluster in my teaching. 
15. I can see clearly how I would develop digital literacies cluster in my teaching.

16. In my teaching I plan to include global themes and topics even from areas outside of my textbook.

17. I feel well-informed what global skills are.

18. It is clear to me what is labelled as global themes.

19. I am ready to cooperate with other teachers on global themes.

Consequently, the research focused on identification of possible correlations between individual items of the questionnaire. As can be seen from the Table 3 there are strong correlations (Tab. 3 red, highlighted) between the items 17 and 18 (0.72), 8 and 19 (0.66), 10 and 9 (0.64) and the items 19 and 7 (0.62).

\section{Table 3 Correlations between individual items}

\begin{tabular}{|c|c|c|c|c|c|c|c|c|c|c|c|c|c|c|c|c|c|c|c|}
\hline \multirow[b]{2}{*}{ Variable } & \multicolumn{7}{|c|}{$\begin{array}{l}\text { Correlations (CLIL vs GS) } \\
\text { Marked correlations are significant at } p<, 05000 \\
\mathrm{~N}=35 \text { (Casewise deletion of missing data) }\end{array}$} & \multirow[b]{2}{*}{ Q8 } & \multirow[b]{2}{*}{ Q9 } & \multirow[b]{2}{*}{ Q10 } & \multirow[b]{2}{*}{ Q11 } & \multirow[b]{2}{*}{ Q12 } & \multirow[b]{2}{*}{ Q13 } & \multirow[b]{2}{*}{ Q14 } & \multirow[b]{2}{*}{ Q15 } & \multirow[b]{2}{*}{ Q16 } & \multirow[b]{2}{*}{ Q17 } & \multirow[b]{2}{*}{ Q18 } & \multirow[b]{2}{*}{ Q19 } \\
\hline & Q1 & Q2 & Q3 & $\mathrm{Q} 4$ & Q5 & Q6 & Q7 & & & & & & & & & & & & \\
\hline Q1 & 1,00 & & & & & & & & & & & & & & & & & & \\
\hline Q2 & 0,06 & 1,00 & & & & & & & & & & & & & & & & & \\
\hline Q3 & 0,09 & 0,29 & 1,00 & & & & & & & & & & & & & & & & \\
\hline Q4 & 0,02 & 0,51 & 0,36 & 1,00 & & & & & & & & & & & & & & & \\
\hline Q5 & $-0,15$ & 0,01 & $-0,25$ & $-0,06$ & 1,00 & & & & & & & & & & & & & & \\
\hline Q6 & 0,24 & 0,57 & 0,35 & 0,37 & 0,01 & 1,00 & & & & & & & & & & & & & \\
\hline Q7 & 0,18 & 0,18 & 0,48 & 0,17 & $-0,29$ & 0,11 & 1,00 & & & & & & & & & & & & \\
\hline Q8 & 0,18 & 0,17 & 0,52 & 0,29 & $-0,10$ & 0,25 & 0,26 & 1,00 & & & & & & & & & & & \\
\hline Q9 & 0,12 & $-0,17$ & 0,24 & 0,25 & 0,13 & $-0,04$ & 0,09 & 0,57 & 1,00 & & & & & & & & & & \\
\hline Q10 & $-0,07$ & 0,08 & 0,09 & 0,24 & 0,24 & $-0,04$ & $-0,04$ & 0,46 & 0,64 & 1,00 & & & & & & & & & \\
\hline Q11 & 0,12 & $-0,09$ & $-0,24$ & $-0,10$ & 0,13 & $-0,33$ & 0,05 & 0,23 & 0,29 & 0,45 & 1,00 & & & & & & & & \\
\hline Q12 & $-0,15$ & 0,14 & 0,01 & $-0,04$ & 0,25 & $-0,05$ & 0,01 & 0,35 & 0,13 & 0,17 & 0,47 & 1,00 & & & & & & & \\
\hline Q13 & 0,27 & 0,14 & 0,21 & 0,04 & 0,13 & 0,10 & 0,36 & 0,45 & 0,12 & 0,09 & 0,44 & 0,67 & 1,00 & & & & & & \\
\hline Q14 & $-0,29$ & $-0,04$ & 0,24 & $-0,16$ & 0,16 & $-0,12$ & 0,34 & 0,15 & 0,17 & 0,23 & 0,24 & 0,24 & 0,38 & 1,00 & & & & & \\
\hline Q15 & 0,17 & 0,04 & 0,34 & 0,11 & $-0,43$ & 0,18 & 0,39 & 0,43 & 0,16 & 0,09 & 0,03 & 0,11 & 0,37 & 0,21 & 1,00 & & & & \\
\hline Q16 & 0,02 & 0,23 & 0,55 & 0,26 & $-0,08$ & 0,07 & 0,07 & 0,44 & 0,40 & 0,32 & 0,15 & 0,19 & 0,21 & 0,24 & 0,28 & 1,00 & & & \\
\hline Q17 & 0,00 & 0,18 & 0,12 & 0,01 & 0,35 & 0,19 & 0,26 & 0,35 & 0,26 & 0,31 & $-0,01$ & 0,24 & 0,10 & 0,23 & 0,10 & 0,12 & 1,00 & & \\
\hline Q18 & 0,07 & 0,21 & 0,20 & 0,24 & 0,03 & 0,14 & 0,11 & 0,42 & 0,34 & 0,43 & $-0,17$ & 0,06 & $-0,07$ & $-0,02$ & 0,18 & 0,11 & 0,72 & 1,00 & \\
\hline Q19 & 0,18 & 0,18 & 0,49 & 0,17 & $-0,33$ & 0,13 & 0,62 & 0,66 & 0,29 & 0,18 & 0,01 & 0,15 & 0,32 & 0,31 & 0,45 & 0,30 & 0,33 & 0,37 & 1,00 \\
\hline
\end{tabular}

Looking at the individual items of strong positive correlation $(\mathrm{p}<.05)$ it can be said that students who scored high in feeling well-informed about global skills also declared a high level of knowledge in global themes (0.72). It was also interesting to see the correlation between communication and readiness to cooperate (0.66) which might signal that more skilled students felt within communication skills the easiest it was for them to envisage possible crosscurricular cooperation with other teachers.

It is important to note that students in general presented a high level of willingness to implement global skills in their teaching (Fig.1) whether in the CLIL lesson (Fig.1, Q4) or in any general lesson of English (Fig.1, Q7). However, their preference towards implementation of global skills into a CLIL lesson is evident. This can be supported by the claim that they can see the space for implementation within the CLIL learning (Fig.1, Q2) due to close connections between the topics usually covered by CLIL and global themes (Fig.1, Q6). What 
seems to be quite promising is that these future teachers expressed a high level of meaningfulness in applying global skills into CLIL lessons (Fig.1, Q3) since making learning meaningful for learners is the attribute that is commonly stressed in teacher training. Traditional teaching does not hold a high credit in this attribute with the prime focus on the form and the linguistic structure.

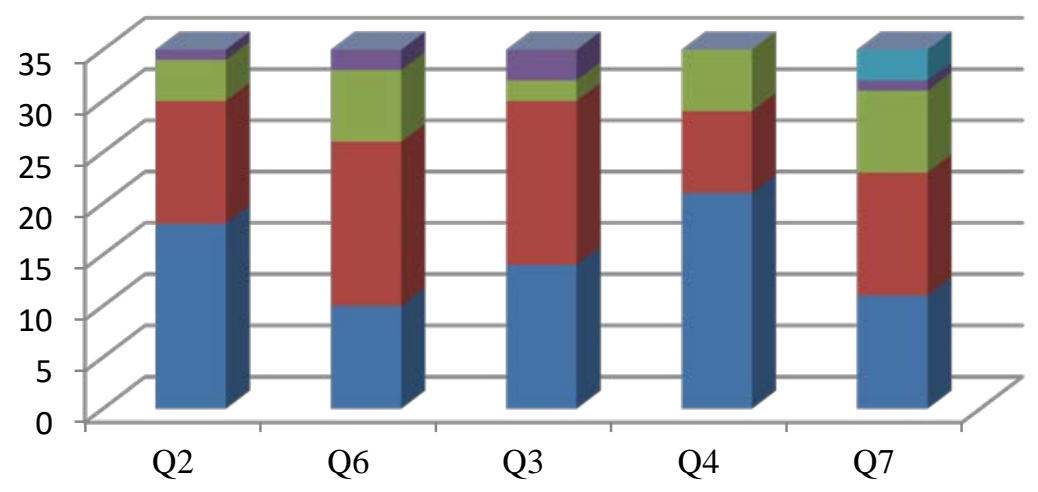

- Strongly disagree

- Moderately disagree

• Slightly disagree

- Not sure

- Slightly agree

- Moderately agree

- Strongly agree

Figure 1 Attitude towards application of global skills in teaching

Since there was a decision to apply the framework of 5 global skills clusters (Mercer et al., 2019) the presentation and subsequent practical application was focused on how these clusters could be applied in teaching.

It was also interesting to see how quickly the students got acquainted with the proposed framework consisting of five clusters of global skills. They even considered themselves ready to apply all clusters in their teaching with ease (Fig.2). Even though one might expect that because they are language teacher the communication cluster (Fig.3, Q8) would score the highest, it was not the case. The clusters of creativity (Fig.3, Q10) and critical thinking (Fig.3, Q11) scored the highest and should present the readiness to apply these two clusters with the most ease. However, as will be presented later, the focus groups revealed some superficiality in understanding what it means to develop critical thinking. The cluster of creativity was most probably supported by a great importance the concept of creativity in the English language teaching is given to (Cimermanová, 2015). The lowest level of perceived efficacy among students was expressed in citizenship cluster (Fig.3, Q13), where the data might be even positively influenced by five students majoring in Civics (Fig. 2). However, there was a significant correlation (see Tab. 2) between the citizenship cluster and intercultural communication cluster (0.67). This close relationship is supported also by Rascón-Moreno (2013, p. 24). 


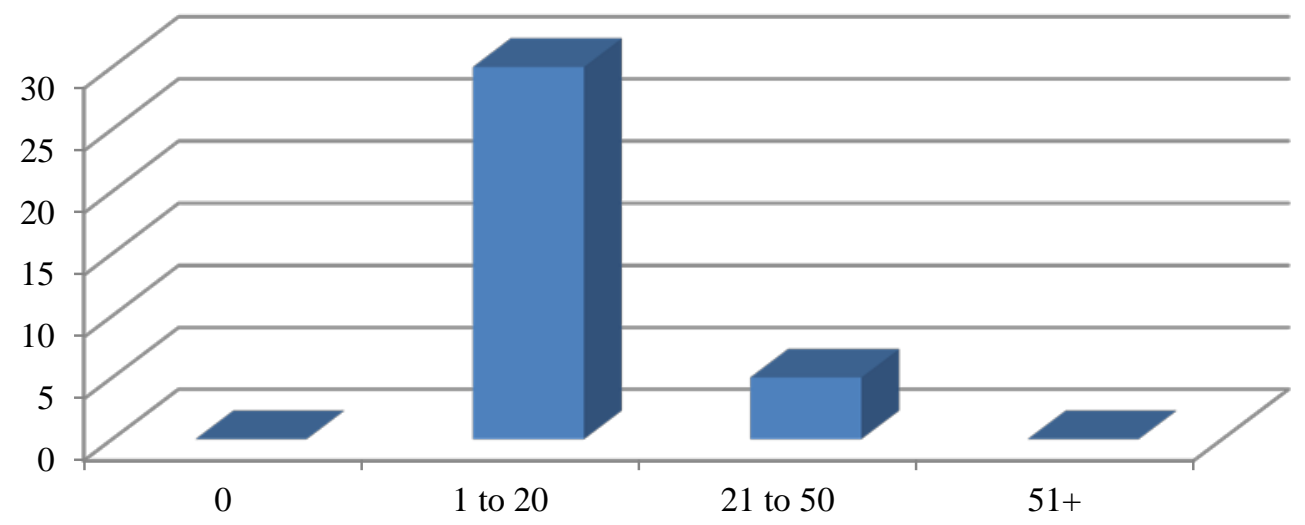

Figure 2 Number of lessons focused on global skills

Surprisingly high scores with very little hesitance can be seen also in the cluster emotional self-regulation and wellbeing (Fig. 3, Q14). This might be explained by the importance that is nowadays given to mental health by the public media which cover these themes more often than in the past. In general it is obvious from the data that students perceive themselves quite ready for the application of any cluster, even though some can be found a bit distant from typical language teaching that students might be accustomed to.

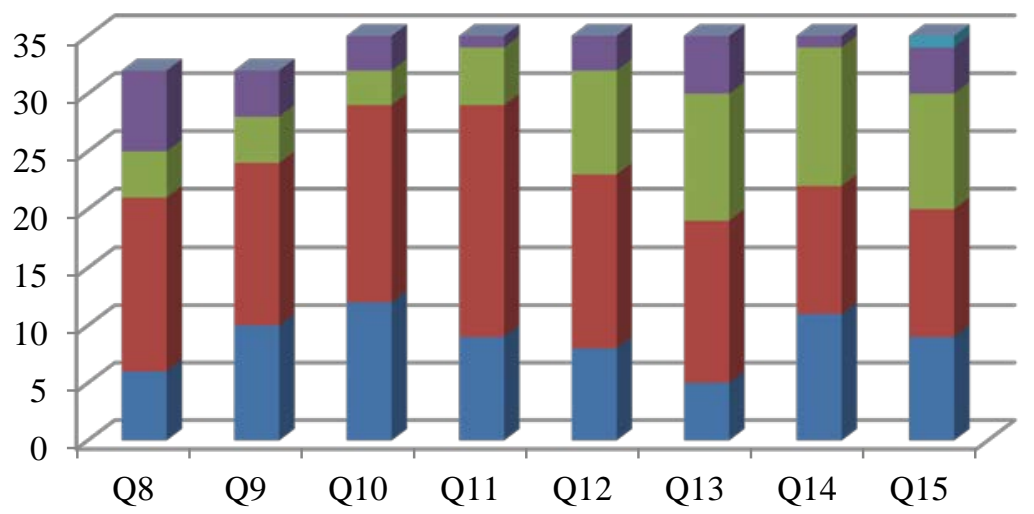

Strongly disagree

- Moderately disagree

- Slightly disagree

Not sure

- Slightly agree

- Moderately agree

- Strongly agree

Figure 3 Perceived ability to implement global skills clusters

Considering the teacher preparation in the context of global skills training the students surprisingly feel prepared well enough for implementation of global skills in their teaching. They demonstrated a high level of readiness in include in their teaching global themes on top of their textbook (Fig.4, Q16) together with clear understanding what is meant by these themes (Fig.4, Q18). They expressed satisfactory level of being informed about global skills as such (Fig.4, Q17) which might have been taken by students as offering a feedback to the lecturer. 
Otherwise it is rather hard to accept the fact that after three lessons of intervention they might feel that well-informed.

On the other hand what can be viewed as positive is their willingness to cooperate with other teachers (Fig.4, Q19) while working on CLIL and global skills since teacher cooperation is one of the most crucial conditions for the successful incorporation of CLIL into teaching (Cimermanová, 2017).

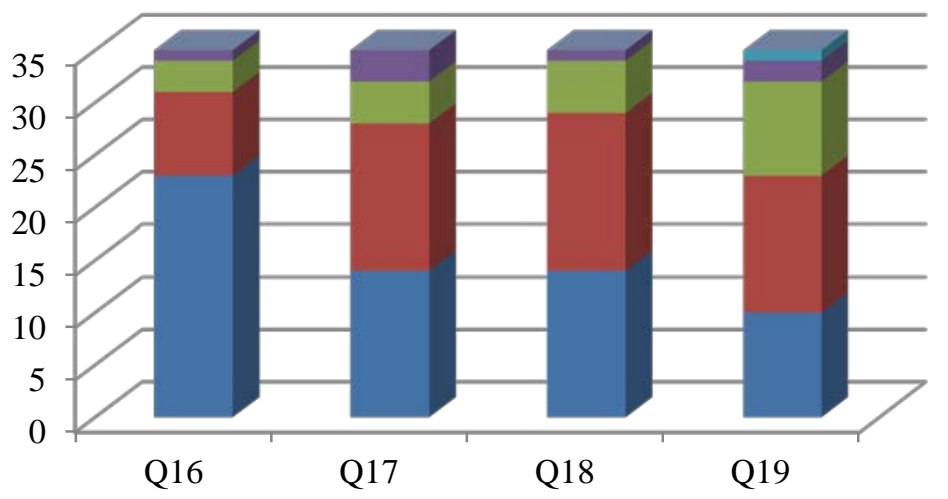

Figure 4 Readiness based on teacher training

- Strongly disagree
Moderately disagree
- Slightly disagree
- Not sure
- Slightly agree
- Moderately agree
- Strongly agree

- Strongly disagree

ongly agree

\section{Conclusions}

Education in the new millennium has changed significantly since the needs of new generations of young people differ from those of the past. The influence of globalisation has left its imprints not only on the ways teachers approach learning nowadays, e.g. in search of meaningfulness, but also it influenced the choice of the topics and skills covered by curricula.

Preparing new teachers for proper functioning in such context is rather demanding due to the complexity of the issue. Yet, as the data indicate, the attention paid to preparing future teachers for global themes and global skills training is rather limited. Unless students major in a subject directly connected to global themes, such as civics, they will not become acquainted with the issue of global skills at all. This might explain the findings of S. Pokrivčáková (2013) that even though CLIL can be located in the Slovak schools, yet teachers have not adapted the way they teach, still preferring traditional form-oriented, teacherbased approach with convergent tasks. It thus seems to be crucial for the change to come into existence to start at pre-service teacher training in order to see the innovative approach in practice.

Since language education offers space for including a wide variety of topics it is more than natural that teachers should search for such topics that would help students to acquire meaningful context through mastering such skills that will be relevant for their future profession. Connecting content and language 
development provides learners with opportunities to do so. As evident from the data presented future teachers were able to grasp the importance of developing global skills even after a limited intervention.

Based on the research outcomes it seems necessary to implement thorough preparation for the use of global themes and the development of global skills across curriculum, i.e. even in the subjects that are not directly connected with the global context. It seems that besides focusing on isolated language items, or skills, it is also necessary to find proper grounding in a meaningful context and head towards meaningful learning outcomes.

\section{Acknowledgement}

This study is a part of a research project financed by the Slovak Ministry of Education, Science, Research and Sport (KEGA 032PU-4/2019, project: Creating teaching materials for content and language integrated learning at elementary schools).

\section{References}

Cenoz, J. (2013). Discussion: towards an educational perspective in CLIL language policy and pedagogical practice. International Journal of Bilingual Education and Bilingualism, 16(3), 389-394, DOI: 10.1080/13670050.2013.777392

Cimermanová, I. (2015). Creativity in EFL teacher training and its transfer to language teaching. Proceedia - Social and Behavioral Sciences, 197, 1969-1975.

Cimermanová, I. (2017). CLIL - a dialogue between the language and subject teachers. Scientia et eruditio 1(1), 1-14. Retrieved from http://pdf.truni.sk/see/issue?2017-en\&naturalsciences\#CIMERMANOVA

Cummins, J. (1998). Immersion education for the millennium: What have we learned from 30 years of research on second language immersion? In M.R. Childs \& R.M. Bostwick (Eds.), Learning through two languages: Research and practice. (pp. 34-47). Katoh Gakuen, Japan.

Díaz-Pérez, F.J. (2013). Introduction to Global Issues in the Teaching of Language, Literature and Linguistics. In Díaz-Pérez, F.J., Belén Díez-Bedmar, M., García-Ramírez, P. \& Rascón-Moreno, D. (Eds.), Global Issues in the Teaching of Language, Literature and Linguistics (pp. 7-14). Bern: Peter Lang AG.

Dalton-Puffer, Ch. (2011). Content-and-Language Integrated Learning: From Practice to Principles? Annual Review of Applied Linguistics, 31, 182-204.

Jakar, V. (2004). Promoting global issues. GISIG Newsletter 16, 24-26.

Klieme, E., Hartig, J., \& Rauch, D. (2008). The Concept of Competence in Educational Contexts. In J. Hartig, E. Klieme \& D. Leutner (Eds.). Assessment of Competencies in Educational Contexts (pp. 3-22). Ashland: Hogrefe \& Huber publishers.

Lasagabaster, D. (2011). English achievement and student motivation in CLIL and EFL settings. Innovation in Language Learning and Teaching 5(1), 3-18. DOI:10.1080/17501229.2010.519030

Lasagabaster, D., \& Sierra, J. M. (2010). Immersion and CLIL in English: More Differences than Similarities. ELT Journal 64(4), 367-375. DOI:10.1093/elt/ccp082 
Llinares, A. (2015). Integration in CLIL: a proposal to inform research and successful pedagogy. Language, Culture and Curriculum 28(1), 58-73.

DOI: 10.1080/07908318.2014.1000925

Lorenzo, F., Casal, S., \& Moore, P. (2010). The effects of content and language integrated learning in European education: Key findings from the Andalusian bilingual sections evaluation project. Applied Linguistics 31, 418-442.

Marsh, D. (2002). CLIL/EMILE: The European Dimension-Actions, Trends and Foresight Potential. Retrieved from https://jyx.jyu.fi/bitstream/handle/123456789/47616/1/ david_marsh-report.pdf

Marsh, D. (2006). English as medium of instruction in the new global linguistic order: Global characteristics, local consequences. In Stewart, S.M., Olearski, J.E., \& Thompson, D. (Eds.), Proceedings of the Second Annual Conference for Middle East Teachers of Science, Mathematics and Computing (pp. 29-38). Abu Dhabi: METSMaC.

Mehisto, P. (2008). CLIL Counterweights: Recognising and Decreasing Disjuncture in CLIL, International CLIL Research Journal 1(1), 96-117.

Mehisto, P. (2012). Criteria for producing CLILlearning material. Encuentro, 21, 15-33.

Met, M. (1998). Curriculum decision-making in content-based language teaching. In Cenoz, J., \& Genesee, F. (Eds.), Beyond bilingualism: Multilingualism and multilingual education (pp. 35-63). Clevedon: Multilingual Matters.

OECD. (2016). Definition and selection of competencies. (DeSeCo). Retrieved from http://www.oecd.org/education/skills-beyondschool/definitionandselectionofcompetenciesdeseco.htm

Pokrivčáková, S., Menzlová, B., \& Farkašová, E. (2010). Creating conditions for effective application of CLIL methodology in Slovakia. In: Modernization of Teaching Foreign Languages: CLIL, Inclusive and Intercultural Education (23-28). Brno: Masarykova univerzita.

Pokrivčáková, S. (2013). CLIL Research in Slovakia. Hradec Králové: Gaudeamus, University of Hradec Králové Press.

Rascón-Moreno, D. (2013). Combining Global Issues and English Teaching. In Díaz-Pérez, F.J., Belén Díez-Bedmar, M., García-Ramírez, P., \& Rascón-Moreno, D. (Eds.), Global Issues in the Teaching of Language, Literature and Linguistics (pp. 15-38). Bern: Peter Lang AG.

Ridder, J.W.H. (2004). Letter from the acting SIG Coordinator. GISIG Newsletter 16, 3-4.

Ruiz de Zarobe, Y., \& Cenoz, J. (2015). Way forward in the 21st century in content-based instruction: moving towards integration. Language, Culture and Curriculum 28(1), 90 96. DOI 10.1080/07908318.2014.1000927

Rychen, D.S., \& Salganik, L.H. (Eds.). (2003). Key Competencies for a successful life and wellfunctioning society. Ashland: Hogrefe \& Huber Publishers.

Sepešiová, M. (2015). CLIL lesson planning. In: Modernization of Teaching Foreign Languages: CLIL, Inclusive and Intercultural Education (131-152). Brno: Masarykova univerzita.

Sylvén, L.K. (2013). CLIL in Sweden - why does it not work? A metaperspective on CLIL across contexts in Europe. International Journal of Bilingual Education and Bilingualism 16(3), 301-320. DOI: 10.1080/13670050.2013.777387

UNESCO. (2007). Education for Sustainable Development Goals: Learning Objectives. Paris, France, Retrieved from http://unesdoc.unesco.org/images/0024/002474/247444e.pdf 
Urmeneta, C.E. (2013). Learning to become a CLIL teacher: teaching, reflection and professional development. International Journal of Bilingual Education and Bilingualism 16(3), 334-353. DOI: 10.1080/13670050.2013.777389

Wiek, A., Withycombe, L., \& Redman, C.L. (2011). Key competencies in sustainability: a reference framework for academic program development. Sustain Sci., 6, 203-218. DOI: 10.1007/s11625-001-0132-6 